\title{
Balkanologie
}

Balkanologie Revue d'études pluridisciplinaires

Vol. VI, $n^{\circ}$ 1-2 | 2002

Volume VI Numéro 1-2

\section{Rural-urban differences and the break-up of Yugoslavia}

L'opposition ville-campagne et la dissolution de la Yougoslavie

John B. Allcock

\section{(2) OpenEdition}

1 Journals

\section{Electronic version}

URL: http://journals.openedition.org/balkanologie/447

DOI: $10.4000 /$ balkanologie.447

ISSN: 1965-0582

\section{Publisher}

Association française d'études sur les Balkans (Afebalk)

\section{Printed version}

Date of publication: 1 December 2002

Number of pages: 101-125

ISSN: 1279-7952

\section{Electronic reference}

John B. Allcock, « Rural-urban differences and the break-up of Yugoslavia », Balkanologie [Online], Vol.

$\mathrm{VI}, \mathrm{n}^{\circ} 1-2$ | 2002, Online since 04 February 2009, connection on 17 December 2020. URL : http:// journals.openedition.org/balkanologie/447 ; DOI : https://doi.org/10.4000/balkanologie.447 


\title{
RURAL-URBAN DIFFERENCES AND THE BREAK-UP OF YUGOSLAVIA*
}

\author{
John B. Allcock*
}

\section{INTRODUCTION}

There has been widespread debate over the possible causes of the breakup of the former Yugoslav federation, encompassing a broad choice of political, economic and cultural factors within the country, as well as aspects of its international setting, which might be considered to have undermined the integrity of the state. Relatively little attention has been paid, however, to the importance of rural-urban differences in the development of these social and political conflicts. I set it out in this paper to remind the reader of the importance of this dimension of the disintegration of the former Yugoslavia, although within the format of a brief article it is possible to do no more than illustrate a hypothesis which will certainly require more rigorous empirical examination.

The central hypothesis of this paper is that the economic, political and social exclusion, which some specific segments of the Yugoslav rural population came to experience in relation to the urban-centred "system", can be regarded as having played an important contributory part in the genesis and course of the struggles surrounding the break-up of the former federation. This broad hypothesis is explored here through the medium of two specific, regional casestudies-the ethnic Serb krajina within Croatia, and secessionist "Herceg-

\footnotetext{
- An early version of this paper was read at the $31^{\text {st }}$. Annual Convention of the American Association for the Advancement of Slavic Studies, St. Louis, MO: 18-21 November 1999. A revised version was presented to the Centre for South-East European Studies at the School of Slavonic and East European Studies, London, on 23 October 2001. I am grateful to colleagues who were present on these occasions for their helpful critical comment, as I am also to the anonymous readers appointed by Balkanologie. 
Bosna" within Bosnia and Herzegovina. Before engaging with these particular cases, however, it will be useful to frame discussion in relation to some relevant general issues.

The general differences between urban and rural cultures have been commented upon extensively by sociologists and anthropologists, and are sufficiently well-established not to require detailed elaboration in this context. They include typically, inter alia, the predominance of industrial and commercial occupations, a higher degree of secularisation, wider distribution of education, higher standards of living, smaller family size, reduced importance of kinship, greater exposure to mass communication, and greater involvement in organised political activity on the part of urban in comparison with rural populations.

Whereas these differences are commonly associated with the urban-rural divide in all parts of the world, the creation of differentiated urban cultures in the Balkans has generally been intensified by the historical association of cities with ethnic difference. Under the great imperial powers (Habsburg, Ottoman and Venetian) the cities were identified with Austrian, Magyar or Ottoman ruling élites, and typically also with commercial and financial interests which were differentiated on ethnic grounds, such as Jews, Cincars, Greeks, Ragusans or Germans. In the former Ottoman regions urban-rural differences tended to be made more visible by the institution of millet $t^{1}$. This overlay of ethnic difference intensified the perception of cities by the country-people as foreign and oppressive, and of the villages by the town dwellers as ignorant and backward.

These historical divisions were in no way reduced during the life of the "First Yugoslavia". Although politics was dominated by a configuration of parties which sought to found their legitimacy upon the base of the peasantry, the link was more typically one of a patronising, populist appeal directed by urban élites rather than an organic expression of rural perceptions and needs. The major legislative intervention made by the state in this period, the land reform programme, despite its rhetoric of support for the small farmer, resulted in practice in a succession of horse-trading deals between party leaderships, the primary objective of which appears to have been the securing of parliamentary coalitions ${ }^{2}$.

\footnotetext{
${ }^{1}$ Xavier Bougarel has usefully drawn attention to the significance of this feature. Bougarel (Xarier), Bosnie : anatomie d'un conflit, Paris : La Découverte, 1996. pp. 27-28.

${ }^{2}$ This area is handled from different points of view by Tomasevich (Jozo), Peasants, Politics and Economic Change, Stanford University Press, 1955; Banac (Ivo), The National Question in Yugoslavia, Ithaca / London : Comell University Press, 1984 ; and Djilas (Aleksa), The Contested Country : Yugoslav Unity and Communist Revolution, 1919-1953, Cambridge : Harvard University Press, 1991.
} 
The area which became Yugoslavia was slow to urbanise in comparison with many other parts of Europe. In 1921 there were only six towns in the kingdom with populations greater than 50000 , and only 29 with populations greater than $10000^{3}$. By 1981 Yugoslavia possessed 37 cities with populations greater than 50. Although the Communist Party came to power in 1945 with the aid of a largely peasant army, it could scarcely be regarded as an agent of rural interests. Following a brief interlude of 1945-1948, characterised by further redistribution of land to the small peasants, the attempted collectivisation of agriculture in 1948 ushered in a period of open attack upon the peasant land-holding. Even when the collectivisation programme was abandoned in 1953 it was replaced by a succession of institutions and policies which conveyed at best the indifference of the regime to the countryside, and which embodied the expectation that the peasantry would shortly become absorbed into the manual working class. The treatment of agriculture in "Titoist" Yugoslavia continued, only in a different outward form, the imposition upon the countryside of essentially urban views of the nature and direction of development, noted by Doreen Warriner4.

The situation has been summed up well by Bernard Rosier : "The peasantry and the village are (...) denigrated and suspect. For years now the private cultivator has not been regarded as a proper producer, but as a proprietor, a petty capitalist, who has no place within a socialist system " 5 . In short, the peasant came to be regarded by policy-makers located in the cities as no more than an "obstacle to modernisation "6.

There is some evidence that with the collapse of the former Yugoslavia the socialist straight-jacket of thinking with respect to the countryside has been loosened. Earlier limitations upon the size of individual land-holdings, and the number of employees permitted to private entrepreneurs in general, have been abandoned. Two points are worth making in this regard. In the first place, there is as yet no reason to believe that agricultural policy has ceased to be made principally by "urban thinkers", and by reference to standards of relevance which are determined substantially in capital cities. Secondly, there is equally little reason to believe that the sense of social and cultural distance be-

3 Statistički Godišnjak 1918-1989, Belgrade : SZS, 1989. Table 3-14-

4 See Warriner (Doreen), " Urban thinkers and peasant policy in Yugoslavia, 1918-1959 ", Slavonic \& East European Review, December 1959, pp. 59-81. Note the tendency to assume this explicitly in Yugoslav sociology. See also Allcock (John B.), Explaining Yugoslavia, London / New York : C. Hurst / Columbia University Press, 2000 (Chap. 5, « Economic modernisation : the agrarian economy $n$ ).

5 Rosier (Bernard), éd., Agriculture moderne et socialisme. Une expérience yougoslave, Paris : Presses Universitaire de France, 1968, p. 286.

6 The phrase is from Lazic (Mladen), ed., Society in Crisis : Yugoslavia in the early 19gos, Belgrade : Filip Višnjić, 1995, p. 18. 
tween town and country has been everywhere eliminated7. It is essential at this point, however, to enter three broad caveats.

Claims about the sense of distance which separated the Yugoslav village from the town should not be confused with complete cultural isolation. As anthropological investigators of rural life documented fully, the post-1945 period saw a steady reduction in many of the former cultural differences between rural and urban ways of life ${ }^{8}$. In this respect it is necessary to underline the point that the sense of perceived distance, and the manner in which this comes to be represented in discourses, might not always vary with objectively measured differences in the degree of modernisation between rural and urban $\mathrm{mi}$ lieux.

One fact which emerges regularly from anthropological studies, the significance of which can hardly be over-emphasised, is the enormous variation in the situation of different localities in the Yugoslav region' 9 . For this reason I wish to emphasise that the aim of this paper is to draw attention to the general significance of the dimension of rural-urban differences for the understanding of the transformation of Yugoslavia, rather than to advance any concrete empirical generalisation about the ways in which these can be regarded as having systematic relevance.

In particular, therefore, although the two case-studies presented here focus upon the relative economic backwardness of the regions in question, it certainly cannot be assumed that this is universally the most important dimension of rural-urban relations in the genesis of the Yugoslav conflict.

7 A related account of the historical development of rural-urban differences, which is immensely insightful, is provided by Vujović (Sreten), "An uneasy view of the city ", in Popov (Nebojša), ed., The Road to War in Serbia : trauma and catharsis, Belgrade / Budapest : CEU Press, 2000, pp. 123-145. An added sophistication of the argument is his indication of the importance of the difference between small town mentality and urban culture proper.

${ }^{8}$ See for examples, Halpern (Joel), A Serbian Village, New York : Columbia University Press, 1958 ; Halpern (Joel), Kerewsky-Halpern (Barbara), A Serbian Village in Historical Perspective, New York : Holt, Reinhart \& Winston, 1972 ; Lockwood (William G.), European Muslims : economy and ethnicity in western Bosnia, New York : Academy Press, 1975 ; Winner (Irene), Žerovnica : a Slovenian village, Providence : Brown University Press, 1971. The classic study by Andrei Simić is a particularly important reminder of this point. Simić (Andrei), Peasant Urbanites : a study of rural-urban mobility in Serbia, New York / London : Seminar Press, 1973. I am grateful to Joel Halpern for his observations on this matter.

9 Although it is possible to identify several good studies of specific localities in the Yugoslav region, in relation to the tremendous diversity in the ecology, history, culture and social structure of different regions, social science is still badly lacking on this score. This is particularly the case with the absence of good studies of local history, where the path-breaking work of Bogdan Stojsavljevic still does not have enough imitators (Stojsavljević (Bogdan), "Istorijski razvitak agrarno-ekonomskih odnosa u selu Jalžabet (1839-1939) ", Sociologija, 4 (1-2), 1962). Just as synthetic history can not be undertaken adequately without a foundation of fine-grained work of this kind, so synthetic sociology or anthropology depend upon the construction of a substructure of particularistic investigations. 


\section{SOME ALTERNATIVE APPROACHES TO THE QUESTION}

Before turning to a consideration of the relevant evidence it will be useful to differentiate clearly between the approach which I take here and three types of argument concerning rural-urban differences, which have been advanced elsewhere in recent years.

The first of these emphasises presumed psychological and cultural characteristics, which supposedly distinguish rural from urban populations in the region, deeply rooted in history. The second presents an implicit model of rural communities as passive victims of pressures to change, understood as originating elsewhere. The third centres upon institutionalised models of rural resistance against the state.

\section{Meštrović and « social character 》}

It is vitally important to distinguish the argument developed here from the position taken by another author who has addressed, in his own way, the question of the relevance of rural-urban differences in understanding the break-up of Yugoslavia. I have in mind the work of the American sociologist Stjepan Meštrović.

Stjepan Meštrović has produced a succession of publications since 1993 in which he has sought to revive the work of Dinko Tomašić ${ }^{10}$. Tomašić issued in 1948 his Personality and Culture in Eastern European Politics, in which he argued that the peoples of the Balkan region could be divided into two broad types, ethnographically speaking ("zadruga" culture and "dinaric" culture). These were founded upon different types of ecology, yielding contrasting ways of life, which, he believed, gave rise to opposed personality types. His argument was that the history of the Balkan region in particular, but also eastern Europe more generally, could be understood in terms of cycles of conflict between these antithetical cultures. Tomašic interpreted the history of the Balkans in terms of a series of cycles in which the war-like "dinaric" pastoralists periodically descended from the hills to impose themselves upon the peaceful "zadruga" cultivators. Following victory, they settled in towns, became assimilated by the lowlanders, and embarked upon a process of decadence, to be replaced before long by another wave of "dinaric" conquest.

Although largely discredited since its publication, the work of Tomašić has been taken up again by Meštrović's theory of "social character", as provid-

${ }^{10}$ Especially Meštrović (Stjepan), Goreta (Miroslav), Letica (Slaven), Habits of the Balkan Heart, College Station : Texas A\&M University Press, 1993 ; and Meštrović (Stjepan), The Balkanization of the West, London / New York : Routledge, 1994. Tomasić (Dinko), Personality and Culture in Eastern European Politics. New York : George W. Stewart, 1948. 
ing the basis for an interpretation of events surrounding the collapse of Yugoslavia. Meštrović goes beyond Tomašić in a number of respects, particularly in that he quickly abandons the relatively firm ecological footing of the latter's ideas, and frequently falls into a simple equation between "dinaric" peoples and Serbs and Montenegrins, and "zadruga" types and Croats, which is in danger of being read as straightforward racism ${ }^{11}$. In this approach, patterns of "social character" provide a relatively permanent matrix from which the antagonistic relationship of town and country is reproduced, and the recent conflict must be understood only as the latest in an unending series of cycles. I maintain that what Meštrović constructs is an explanation which is both reductivist and inconsistent with the evidence ${ }^{12}$.

Although the work of Meštrovic has received a generally unsympathetic reception among social scientists, it is worth noting because of the popularity of this type of explanation among intellectuals within the region. Bojan Baskar has warned that : " Depicting war as an accomplishment of anti-urban savages from the Dinaric region is also a standard interpretation by the Belgrade opposition, which is desperately interested in situating the evil in the rural area, in order to be capable of believing in its own innocence ${ }^{13}$.

It is certainly not only among Croats that this kind of over-simple and reductionist explanation for the war has found a sympathetic hearing.

\section{Sociologija Sela and the « externality » of war}

Not surprisingly, social scientists from the Yugoslav region have devoted a good deal of attention to explaining the fate of their former country. It is remarkable, however, that a consideration of rural-urban relations has played a relatively small part in this endeavour ${ }^{14}$. The search for causal factors has focussed very largely upon issues relating to the constitutional and political structure of the former federation. Only in the journal Sociologija Sela has

\footnotetext{
${ }^{11}$ It also happens to be anthropological nonsense, for reasons which it would be distracting to enumerate here. Note that I do not believe that Meštrović does hold racist views, but that what he writes is in danger of this interpretation. Note also that there is an unacknowledged tendency in his work to confuse what was originally a hypothesis about conflict between rural cultures with a model of rural-urban conflict. To say the very least, in the words of Bojan Baskar, this is an approach which is " obviously doomed to parody ". Baskar (Bojan), " Anthropologists facing the collapse of Yugoslavia ", Diogenes, 47 (188), 1999, p. 60.

${ }^{12}$ For some critical reviews of Meštrovic, see : Contemporary Sociology, 24 (1), 1995 pp. 33-35; Foreign Affairs, 74 (2), 1995, pp. 143-144 ; International Affairs, 71 (1), 1995, pp. 172-173 ; Slavic Review, 54 (3), 1995, pp. 813-814 ; Sociology, 29 (2), 1995, pp. 376-378 ; Journal of Economic Issues, 31 (1), 1997, pp. 233-234 ; Slavonic \& East European Review, 75 (3), 1997, pp. 574-576. I am considering the production of a more systematic appraisal of his work in a subsequent publication.
}

${ }^{13}$ Baskar (Bojan), art.cit., p. 61.

${ }^{14}$ The field is extensive, but several examples available in English are : Sekelj (Laslo), Yugoslavia : the process of disintegration, Boulder / New York : Social Science Monographs / Columbia University Press, 1993; Lazić (Mladen), ed., op. cit. ; Akhavan (Payam), Howse (Robert), eds., Yugoslavia, the Former and Future : reflections by scholars from the region, Washington / Geneva : The Brookings Institution / United Nations 
there been anything like a proper acknowledgement of the experience of war by the rural population. Even here, however, it is notable that academic attention has been centred upon the costs and consequences of war, rather than upon its causation ${ }^{15}$.

Although the subject of the implication of the countryside in the causation of war is never the primary concern of writers on rural affairs, a consistent implicit model emerges from several articles which set out to address other problems. War comes into the village, and has a dramatic impact upon the lives of the villagers, but its explanation is invariably to be sought elsewhere. The nearest thing to an attempt at explicit theorisation of the war is provided by Vlasta Ilišin, in an article which takes as its main concern issues relating to post-war reconstruction. His comments on the causation of the war focus on the distance between political institutions and the people, and on the contradiction between " the individual as the bearer of individual interest and the state as the representative of the general interest ${ }^{16}$. In this respect he identifies one element of what appears to be a broad consensus about the disintegration of Yugoslavia among social scientists from the region. The point is, however, that the state is something external to, and distant from, the village.

Similar imagery recurs, stated less abstractly, but phrased more dramatically, in a group of detailed studies of the encounter of particular rural communities with war. Josip Kel has provided us with a study of the mainly ethnic Magyar community of Korodj ; Simun Peneva with an account of the experience of Tovarnik ; the local "Crisis Committee" wrote a description of events at the outbreak of the war in Lovas ; and Mato Batorović and Stipan Kraljevic have reviewed events in Ilok-all settlements located in eastern Slavonija and incorporated into the Serbian krajina between 1991 and 1996. For Kel, war simply arrives in Koradj on the 19 June 1991, as a result of the activity of the "JNA $i$ Cetnici "17. Likewise Lovas is the victim of "aggression" by the Srbovojska ${ }^{18}$.

Research Institute for Social Development, 1995 ; Pavković (Aleksandar), The Fragmentation of Yugoslavia : nationalism and war in the Balkans, London : Macmillan (2 ${ }^{\text {nd }}$ ed.), 2000 ; Popov (Nebojša), ed., op.cit. It is interesting to observe, in passing, that the factor of ethnic difference tends to be treated by Yugoslav social scientists as a dependent rather than an independent variable, in contrast to the work of outsiders such as Paul Mojzes. Mojzes (Paul), Yugoslavian Inferno : ethnoreligious war in the Balkans, New York : Continuum, 1994) and Michael Sells (Sells (Michael), The Bridge Betrayed : religion and genocide in Bosnia, Berkeley : University of California Press, 1996).

${ }^{15}$ A related area of interest, not unnaturally, is that of post-war reconstruction. Vol. 30 (1-2) of Sociologija Sela, in 1992, was devoted in its entirety to Rat i obnova (War and reconstruction).

${ }^{16}$ Ilišin (Vlasta), " Rat, problemi obnove i politička opredjeljenja grasdske i seoske mladeži u Hrvatskoj ", Sociologija Sela, 31 (1-2), 1993 , p. 76.

${ }^{17}$ Kel (Josip), " Korodj : što smo nam se dogodilo u domovinskom ratu ? ", Sociologija Sela, 34 (1-2), 1996, p. 120.

${ }^{18}$ Krizni štab Lovasa, « Istina o stradanju selu Lovasa i njegovih žitelja za vrijeme okupacije Srbočetničke vojske ", Sociologija Sela, 30 (3-4), 1992, p. 291. 
Peneva's account of Tovarnik devotes a little more space to the antecedents of war. Nevertheless (in a village with a Serb minority of around $22 \%$ ) the foundation of the Serbian Democratic Party takes place as a result of external initiative, and the village is drawn into conflict following the events in Borovo Selo on 2 May $1991^{19}$. The same elements of externality recur in Batorovic and Kraljić's study of Ilok, where war is portrayed simply as a consequence of Velikosrpska politika-" the creation of a unitaristic Yugoslavia and a Great Serbia $" 20$. Ilok is directly affected first by the desecration of the local Orthodox graveyard on 27 March 1991, although this is interpreted not as evidence of local ethnic hostility but as a "provocation" directed at local Serbs and initiated elsewhere. Local solidarity is disrupted by the intrusion of externally manufactured enmities. (Even "Zagreb" is regarded with suspicion, as the authorities attempt to "hush up" the incident.) The local impact of the ambush at Borovo Selo is similarly dramatic, though distant ${ }^{21}$. For all of these authors, if one wishes to understand the war it would be a waste of time to look for causal factors in the villages themselves.

\section{Rural resistance against the state}

A far more complex, and interesting, appraisal of the relationship between town and country in the causation of the Yugoslav wars is provided by Xavier Bougarel. Taking as his point of critical departure the Tomašić-Meštrovic thesis, he reviews a series of institutionalised models of rural resistance against the state. He interprets the story which extends "from hajduks to police auxiliaries ", however, in terms of : "imbalances in the modernization of Yugoslav society [which] provoked its "retraditionalization", expressed by the resurgence of nationalist ideologies and communalist practices in political life, and by the reactivation of clan and kin solidarities $"^{22}$.

In place of an explanation in terms of primordial traits of "social character" which ineluctably assert themselves in defiance of all superficial appearances of socio-cultural change, Bougarel offers us a much more sophisticated account, according to which historically available models of behaviour are activated in response to the contemporary problem of the "incompletion of the

19 Peneva (Simun), « Memento za Tovarnik, svibanj-rujan 1991 ", Sociologija Sela, 32 (1-2), 1994, Pp. 101-102.

${ }^{20}$ Batorović (Mato), Kraljević (Stipan), " Ilok u okruženju, izlazak u konvoju, Iločani u progonstvu ", Sociologija Sela, 31 (3-4), 1993, p. 184.

${ }^{21}$ Ibid., p. 185.

${ }^{22}$ Bougarel (Xavier), "Yugoslav wars : the "revenge of the countryside" between sociological reality and nationalist myth ", East European Quarterly. XXXII (2), 1999, p. 165. Bougarel remarks, incidentally, on the antiquity of theories of politics which focus on rural-urban opposition, tracing them back to Ibn Khaldun (pp. 161-162). For a closely related argument see Alleock (John B.), op.cit., Chap. 13, "Violence in South Slav Society $n$. 
state"23. He looks at the processes of the state which he regards as conducive to unofficial violence. Violence is not simply imported into the village. His account allows us to appreciate the ways in which violence takes institutional forms and is promoted by discourses which are embedded in the past of the locality ${ }^{24}$.

The approach which I offer here is fundamentally opposed to that of Meštrović, in that I wish to insist upon the need to provide an explanation which is fundamentally historical, rather than immanent or essentialist. I share this aim with Bougarel : and in that respect I wish to offer for consideration factors which complement rather than replace those which the latter discusses. My endeavour is directed to those factors which might be said to "trigger" violence at specific locations within the cultural and political context which he describes.

Looking at the Sociologija Sela studies cited above, it is striking that they all deal with communities located in eastern Slavonia, having preponderant ethnic Croat or Magyar majorities. I suggest that their interpretation of the background to the war is entirely understandable, given that the authors are reporting the experience of people from this particular region. If we shift the focus of our attention to other areas, however, guided by other criteria of selection, then a different view begins to emerge. The purpose of the following discussion is to draw attention to the possible significance of economic factors in the aetiology of violence during the break-up of the former Yugoslav federation, focusing by way of illustration on events in the secessionist Serb krajina within Croatia (excluding central and eastern Slavonia) and upon the ethnic Croat enclave of western Herzegovina.

My own approach, which stands in either a critical or tangential relation to these, while wishing to place contemporary data within a historical context, relies for its explanatory force upon the hypothesis that economic deprivation on the part of certain geographical areas can be considered to have been particularly significant in the development of the Yugoslav conflicts.

\footnotetext{
${ }^{23}$ Bougarel (Xavier), art.cit., pp. 172-173.

${ }^{24}$ An approach which bears several interesting similarities to that of Bougarel is that of Ivan Colović. See Colović (Ivan), Bordel ratnika : folklor, politika i rat, Belgrade : Biblioteka XX vek, 1994. It would be interesting to explore further the links between the explanations offered by Bougarel, Colović and Vujović, but this task lies outside the narrow remit of this paper.
} 


\section{THE IMPORTANCE OF ECONOMIC FACTORS}

Public discussion of the disintegration of the Yugoslav federation, by focussing upon the factor of nationalism, has tended to obscure the importance of economic developments (although in the literature of social science this dimension has been recognised more fully). As the basis of conflict between different groups and regions within Yugoslavia, economic problems were at least as important as politico-cultural factors. The overall economic crisis of the federation also had its part to play in undermining the overall sense of security of all Yugoslavs.

The unification of Yugoslavia brought together into a single state regions with very diverse economies, measured in terms of their size, structure, degree of industrialisation, degree of modernisation, and level of productivity. In 1952 the GDP per capita in Slovenia stood at $181,82 \%$ of the all Yugoslav average, whereas in Kosovo that figure was $46,51 \%$. Serbia occupied a mid-point with a GDP per capita of $101,97 \%$ of the average ${ }^{25}$.

The post-war years, on the whole, were characterised by the growth of these differentials, so that by 1989 the level for Slovenia stood at $196,80 \%$ of the federal average, Serbia as a whole maintained its mid-ranking position with $103,62 \%$, but Kosovo had slumped to $25,66 \%$. Croatia managed to maintain its relative position as a republic throughout this period, with a GDP per capita of $121,39 \%$ of the federal average in 1952, and of $126,26 \%$ in 1989 . Bosnia and Herzegovina, along with the other less-developed regions of the country (Macedonia and Montenegro, as well as Kosovo) tended to fall behind. The figures for Bosnia and Herzegovina declined from 95,50\% in 1952 (not far behind the position of Serbia as a whole, and ahead of the Vojvodina) to $67,92 \%$ in 1989 (only Kosovo and Macedonia falling below this level).

25 The source for the figures in this section is the essays by Vojnic (Dragomar), "Disparity and Disintegration : The Economic Dimension of Yugoslavia's Demise ", in Akhavan (Payam), Howse (Robert), eds., op.cit. It might be worth remarking at this point on a general (albeit speculative) note of caution which needs to be sounded in relation to this discussion, which I have yet to see examined in the literature, but which emerges from a remark made informally by Rado Haluzik. There is a huge question-mark hanging over the adequacy of Yugoslav official economic statistics. I suspect that there were significant, systematic regional variations in the degree of their technical accuracy. In particular, it is not inconceivable that the degree of underestimation of indicators of economic activity varied directly with the degree of economic under-development, with the result that economic backwardness was regularly overestimated in all discussions based upon official statistics. There is probably no way of testing this hypothesis. It seems unlikely, despite their failings, that Yugoslav official figures are so unrepresentative of the facts that, overall, general patterns, such as those with which we are dealing here, are completely obscured by the data. Since my own discussion is necessarily based upon these figures, however, all that I can do is enter a word of caution, while pleading that my own conclusions are likely to be no less wellfounded than any other similarly-based work. 
These growing disparities in economic fortune were a matter of consistent political concern throughout the post-1945 period, and were the subject of redistributive action at first by the General Investment Fund (before the economic reform begun in 1963) and subsequently by the Fund for Supporting the Development of the Underdeveloped Republics and Regions. The fiscal burden which these transfers involved provoked resentment on behalf of the betteroff republics, which tended to argue that the same resources could have been invested to better effect in their territories. They came to regard the poorer regions as an economic burden, generally failing to take into account the advantages which accrued to their economies through the all-Yugoslav market. The failure of the more backward regions to make the expected and hoped for leap forward was blamed upon factors such as the political criteria used to make investment decisions, poor locational factors, and allegations of a culture of inefficiency. The less-developed recipients of aid, dismayed by their continuing slide into relative disadvantage, continued to demand greater efforts from their neighbours.

The controversy over regional economic differences was a primary factor in the upsurge of political dissatisfaction which came to be known as the "Croatian Spring" of 1971-1972. The political response to this crisis took the form of the constitutional reform of 1974, and the "Law on Associated Labour" of 1976 , both of which took the country further down the road to political and economic decentralisation. These reforms exacerbated the structural weaknesses of the Yugoslav economy instead of remedying them. After the "second oil shock" of 1979, the sense of economic insecurity in Yugoslavia began to grow steadily worse. This was heightened dramatically after the IMF and other international creditors, anxious about the world-wide crisis of creditworthiness among less-developed economies, demanded major structural reforms of the Yugoslav government as a condition for further support.

Strong differences emerged within government, business and academic circles in Yugoslavia as to how the economy should be restructured, in which process Slovene and Croatian interests emerged as favouring a rapid transition to marketisation, whereas other republics, led by Serbia, tended to be more sympathetic to a more cautious approach which would retain important features of the communist approach to the political management of the economy. These differences, compounded by differences over the need to re-legitimate government by a parallel transition to multi-party democracy, split the League of Communists during 1989, and led directly to the break-up of the federation. Whereas this argument is widely familiar in the literature, an equally important, although frequently underestimated, feature of this economic picture was the fact that by concentrating attention upon differences between republics the differential economic fate of regions and sectors was often overlooked altogether. 
Although Croatia was consistently one of the economically more developed of the republics, for example, and a net contributor to the federal development funds, there remained within the republic pockets of acute poverty and serious backwardness. Although Bosnia and Herzegovina as a whole was counted among the less-developed republics, there were marked differences between the economic fortunes of different regions within that republic also. In part these regional differences reflected differential attention on the part of policy-makers to the development of different sectors.

Although the first two decades of the "Second Yugoslavia" featured a consistent commitment to industrialisation as the primary plank of the economic platform, this was subsequently modified (in part) by increased attention to other sectors. Consequently, in Croatia after the economic reform of the mid1960 s the building of tourism became an economic objective of major importance. Despite the fanfare with which the idea of a "Green Plan" was announced in 1973, however, in very few localities did agriculture ever take on the role of the leading sector in economic development ${ }^{26}$.

Some rural areas in particular can be shown to be characterised throughout the post-1945 period by steady economic and demographic decline. For a variety of reasons (probably not principally by design) these were frequently areas dominated by ethnic minority settlement. As the Yugoslav economic and political crisis deepened, these came to experience ever more sharply their relative disadvantage. I suggest that their neglect and backwardness tended to result in greatly increased levels of resentment, isolation and frustration on the part of the inhabitants, and as the disintegrating League of Communists was compelled to give way to a configuration of mainly ethno-nationalist parties, the plight of such regions came to be represented sharply in nationalistic terms ${ }^{27}$.

The range of illustrative material which might be assembled in relation to this claim, is considerable. Most notably, genesis of the country's problems in a process of the exacerbation of regional economic differences has been widely discussed, and points at least by implication to this problem ${ }^{28}$. The importance

\footnotetext{
${ }^{26}$ In addition to the generally-acknowledged importance of the Vojvodina in this respect, other examples which might be noted would be the Neretva delta and the Konavlje, in Dalmatia.

${ }^{27}$ This cannot be taken, of course, as a blanket explanation for the strength of extreme nationalism in all its forms in Yugoslavia - witness the relatively vigorous support for the right wing of the HDZ in Split, or for "Arkan" in Serbian towns.

${ }^{28}$ See in particular, Lydall (Harold), Yugoslav Socialism : Theory and Practice, Oxford : Clarendon Press, 1984 (esp. pp. 174-183) ; Iydall (Harold), Yugoslavia in Crisis, Oxford : Clarendon Press, 1989 (esp. Chap. 10); Pleština (Dijana), Regional Development in Communist Yugoslavia, Boulder : Westview Press, 1992 ; Ramet (Sabrina P.), Nationalism and Federalism in Yugoslavia, 1962-1991, Bloomington : Indiana University Press ( $2^{\text {nd }}$ ed.), 1992 (esp. Chap. 8) ; Vojnić (Dragomar), art.cit.
} 
for the continuing hold of Slobodan Miloševićs Socialist Party of Serbia of a predominantly rural vote has also been remarked upon ${ }^{29}$. Such is the scope and complexity of the material which might be considered in this respect that it is necessary in a brief paper that I confine myself to illustrating the problem, rather than attempting anything like a thorough analysis. Consequently I confine my remarks to a consideration of some aspects of the development of political conflict in Bosnia and Herzegovina and Croatia, and in particular to the attempts to create secessionist, ethnic mini-states within these republics-the Serb krajina in Croatia, and "Herceg-Bosna" 30 .

\section{CASE STUDIES : THE SERB KRAJINA IN CROATIA}

The areas of Croatia which came to be incorporated into the Serbian krajina between 1991 and 1995, were predominantly backward rural regions. In the thirteen municipalities (opštine or općine) primarily involved in the setting up of the Croatian Krajina, there were only two settlements with populations greater than 10000 (Knin and Petrinja) ${ }^{31}$. Fewer than 50000 of Croatia's 581000 ethnic Serbs lived in Zagreb (1991 census), and the preponderant majority of them were found in relatively small, mainly rural settlements.

The overall decline of population, especially in rural areas, has long been a matter of general concern in Croatia ${ }^{32}$. Forty seven of the republic's

${ }^{29}$ See a brief review of Serbian sources, in Gordy (Eric D.), The Culture of Power in Serbia, Pennsylvania State University Press, 1999 (" Social bases of regime support ", pp. 51-60) ; also, Allcock (John B.), op.cit, pp. 357-358. For a longer-term view of the importance of " forces of traditional collectivism ", see Perović (Latinka), "The flight from modernization ", in Popov (Nebojša), ed., op.cit., esp. pp. 119-122. Cf. Allcock (John B.), " Rhetorics of nationalism in Yugoslav politics ", in Allcock (John B.), Horton (John J.), Milivojević (Marko), eds., Yugoslavia in Transition, Oxford / New York : Berg, 1992, esp. pp. 291-294.

${ }^{30} \mathrm{Not}$ all of the areas of Croatia in which attempts were made by Serbs to secede from the republic are considered here. I believe that the attempt to detach eastern Slavonia from Croatia was motivated largely by the concerns of Belgrade to secure control over the considerable economic resources of the region. I exclude also the area around Pakrac and Daruvar from discussion. Similarly, the attempt to extend "HercegBosna" into areas of central Bosnia can be understood largely in terms of their significance in terms of communications and power generation. In each case, the "motor" of military action was the strategic interests of state centres elsewhere, rather than local action. In relation to central Bosnia, this case is argued in some detail in Allcock (John B.), Aspects of Ethnicity, Nationality and Nationalism in the former Yugoslavia, Statement of Expert Witness presented to the International Criminal Tribunal for the Former Yugoslavia. Bradford, n.d. See esp. Part I, G, and Maps 7 and 8.

${ }^{31}$ Concise Atlas of the Republic of Croatia, Zagreb : Miroslav Krleža Lexicographical Institute, 1993, p. 109. Note that the figures usually cited for municipalities (communes) typically cover areas larger than their principal settlements. There were other municipalities adjacent to this area, with large Serb populations (particularly Drniš and Otočac) which were partially incorporated into the territory of the krajina. These are excluded from discussion here.

${ }^{32}$ See esp. Nejasmić (Ivica), Depopulizacija u Hrvatskoj : korijeni, stanje, izgledi, Zagreb : Globus / Institut za migracije i narodnosti Sveučilišta u Zagrebu, 1991. 
communes experienced a fall in their population between 1981 and 1991 : and " if the (urban) centres are excluded, only $30 \%$ of the municipalities recorded an increase in population "33. To some extent this pattern is accounted for by patterns of migration, but if one considers only rates of natural increase / decrease, the picture is similar. In the same inter-censal period 49 municipalities failed to reach replacement rate ${ }^{34}$. It seems that the rates of decline were higher in the krajina municipalities than for the republic as a whole. Table 1 compares rates of population / decline in 13 krajina communes and the Republic of Croatia, between 1971 and 1991. The entire area was experiencing population decline, and five municipalities (Dvor, Gračac, Korenica, Slunj and Vrginmost) lost more than a fifth of their population over the two decades 35 .

\section{Table 1 : Population in Selected Communes of Bosnia and Herzegovina and Croatia, 1971, 1981, 1991}

\section{Bosnia and Herzegovina}

\begin{tabular}{|l|r|r|r|r|c|}
\hline & \multicolumn{1}{|c|}{1971} & \multicolumn{1}{|c|}{1981} & $\begin{array}{c}\% \text { Change } \\
(1971-81)\end{array}$ & 1991 & $\begin{array}{c}\% \text { Change } \\
(1971-91)\end{array}$ \\
\hline Republic & 3746111 & 4124256 & $+10,1$ & 4364574 & $+16,5$ \\
Čapljina & 23459 & 26032 & $+11,0$ & 27852 & $+18,7$ \\
\hline Čitluk & 15359 & 14101 & $-9,2$ & 14709 & $-4,2$ \\
Duvno & 33135 & 30666 & $-7,4$ & 29261 & $-11,7$ \\
Grude & 19203 & 17767 & $-7,5$ & 15976 & $-16,9$ \\
Lištica & 27285 & 26076 & $-4,4$ & 26437 & $-3,0$ \\
Livno & 42186 & 40438 & $-4,1$ & 39526 & $-6,3$ \\
Ljubuški & 28269 & 27603 & $-2,4$ & 27182 & $-3,8$ \\
Neum & 4781 & 4030 & $-16,3$ & 4268 & $-10,7$ \\
Posušje & 16882 & 16455 & $-2,5$ & 16659 & $-1,3$ \\
\hline Prozor & 17963 & 19108 & $+6,4$ & 19601 & $+2,8$ \\
\hline
\end{tabular}

33 Concise Atlas of the Republic of Croatia, op.cit., p. 60.

34 Ibid., p. 61.

35 It is important to note the reasons why Slunj is included here. In the census of $1991,63.7 \%$ of the population of the commune were recorded as ethnic Croats. Secessionist Serb forces managed to establish effective control over a substantial portion of the area, however, which remained extremely important to the krajina project as a link between the two principal parts. The commune was included in "Sector North" of the UN "Protected Areas", but was not included by the Republic of Croatia in the "districts with special status" which were set up under the regional government reform of December 1992. (See Concise Atlas of the Republic of Croatia, op.cit., pp. 46-47.) Slunj is typical of a number of municipalities in which there was a marked contrast between the ethnicity of its urban and its rural populations. 
Croatia

\begin{tabular}{|l|r|r|r|r|c|}
\hline & 1971 & 1981 & $\begin{array}{c}\% \text { Change } \\
(1971-81)\end{array}$ & 1991 & $\begin{array}{c}\% \text { Change } \\
(1971-91)\end{array}$ \\
\hline Republic & 4426221 & 4601469 & $+3,6$ & 4784256 & $+8,1$ \\
\hline Benkovac & 35562 & 33549 & $-5,7$ & 33079 & $-7,6$ \\
\hline Donji Lapac & 9609 & 8447 & $-12,1$ & 8049 & $-16,2$ \\
\hline Dvor & 18359 & 16307 & $-11,2$ & 14636 & $-20,3$ \\
\hline Glina & 28336 & 25079 & $-11,5$ & 22997 & $-18,8$ \\
Gračac & 14819 & 11863 & $-19,9$ & 11060 & $-25,4$ \\
\hline Knin & 46679 & 43731 & $-6,3$ & 42337 & $-9,3$ \\
\hline Kostajnica & 16914 & 15548 & $-8,1$ & 14839 & $-12,3$ \\
\hline Obrovac & 13498 & 12362 & $-8,4$ & 11557 & $-14,4$ \\
\hline Petrinja & 31018 & 33570 & $+8,2$ & 35662 & $-15,0$ \\
\hline Slunj & 25835 & 21732 & $-15,9$ & 18643 & $-27,8$ \\
T. Korenica & 14637 & 12261 & $-16,2$ & 11307 & $-22,8$ \\
\hline Vojnić & 9590 & 8908 & $-7,1$ & 8190 & $-14,6$ \\
\hline Vrginmost & 21536 & 18841 & $-12,5$ & 16534 & $-23,2$ \\
\hline
\end{tabular}

Source : For 1971 and 1981, Statistički Godišnjak SFR Jugoslavija, 199o. Belgrade, SZS, 1991 ; for 1991, Concise Atlas.

These rates of decline were influenced heavily by out-migration (especially in the band of settlements lying outside of urban areas, extending from Slunj to Gračac). Although the largest falls in population were recorded in the krajina, infertility was actually a greater problem in central Slavonia. This points towards the distinctive economic dimension of change in the former.

In the 13 communes under review, GNP per capita nowhere exceeded $75 \%$ of the average for the Republic of Croatia, and in four of those (Dvor, Obrovac, Slunj and Vojnic) it was below $50 \%$ of that level ${ }^{36}$. Table 2 provides data relating to the nett income per capita in social sector employment for this area. Of these 13 municipalities, only Knin and Petrinja were ranked higher than $87^{\text {th }}$ out of 115-the only two not to fall into the lowest quartile. Their standing in this respect reflects their importance as urban settlements. Undoubtedly this picture could be elaborated further ; but the evidence considered here suggests that Serb secessionism in Croatia can be understood in substantial measure as a reflection of rural backwardness 37 .

\section{${ }^{36}$ Concise Atlas of the Republic of Croatia, op.cit., p. 63.}

37 A similar picture obtains with respect to the heartland of Serb secessionism in Bosnia and Herzegovina. Of the 19 Bosnian municipalities outside of Sarajevo with populations in 1991 of fewer than 15000,16 had substantial Serb majorities (the exceptions being Jablanica, Kreševo and Neum). Of the six mainly ethnic-Serb municipalities in eastern Hercegovina, Kalinovik and Ljubinje, with populations of fewer than 5000 each, were barely viable as municipalities. 
Table 2 : Nett Income Per Capita in Social Sector Employment Selected Communes of Bosnia and Herzegovina and Croatia, 1988

\section{Bosnia and Herzegovina}

\begin{tabular}{|l|c|c|}
\hline Commune & $\begin{array}{c}\text { Monthly p.c. income } \\
\text { in soc. sect. employment (dinars) }\end{array}$ & $\begin{array}{c}\text { Rank order } \\
\text { (109 communes) }\end{array}$ \\
\hline Čapljina & 3612 & 48 \\
Čitluk & 1601 & 85 \\
\hline Duvno & 1418 & 91 \\
Grude & 981 & 101 \\
\hline Lištica & 1708 & 79 \\
Livno & 3526 & 51 \\
\hline Ljubuški & 1668 & 83 \\
Neum & 439 & 93 \\
Posušje & 1377 & 93 \\
Prozor & 1078 & 98 \\
\hline
\end{tabular}

\section{Croatia}

\begin{tabular}{|l|c|c|}
\hline Commune & $\begin{array}{c}\text { Monthly p.c. income } \\
\text { in soc. sect. employment (dinars) }\end{array}$ & $\begin{array}{c}\text { Rank order } \\
\text { (115 communes) }\end{array}$ \\
\hline Benkovac & 2669 & 88 \\
\hline Donji Lapac & 1216 & 108 \\
Dvor & 1110 & 111 \\
Glina & 2672 & 87 \\
Gračac & 1374 & 105 \\
Knin & 6795 & 42 \\
Kostajnica & 2029 & 97 \\
Obrovac & 1292 & 106 \\
Petrinja & 5208 & 56 \\
Slunj & 1489 & 104 \\
T. Korenica & 2112 & 95 \\
Vojnić & 568 & 115 \\
Vrginmost & 1658 & 102 \\
\hline
\end{tabular}

Source : Statistički Godišnjak SFR Jugoslavija : 199o. Belgrade, SZS, 1991.

Although there may be a tendency in lay or press discussion to treat "Serbs" in Croatia as a single category, there were significant divisions of political culture within the Serb community. The Serbs in general, but particularly in Zagreb and other larger cities, tended to identify themselves politically with the League of Communists, and its Social-Democratic or Socialist succes- 
sors. These parties were quite different in outlook from the supporters of Jovan Rašković and his Serbian Democratic Party (SDS), which made relatively little headway in the capital, but which had solid support in these rural and smalltown populations. It is instructive to examine the results of the first, multiparty elections in Croatia, in April-May $1990^{38}$. The distinctive pattern of Serb voting in the krajina emerges clearly here in Table 3.

\section{Table 3 : Voting in the Krajina Constituencies in the Croatian Elections of 1990}

\section{Chamber of Municipalities - $1^{\text {st }}$ Round (Apr. 22, 1990)}

\begin{tabular}{|l|c|c|c|c|}
\hline Commune & SDP & SDS & SS-SSH & Other \\
\hline Benkovac & 13,2 & & 47,1 & 37,3 (KNS) \\
Donji Lapac & & 46,2 & & 7,6 (Ind), 42,9 (Other)* \\
Dvor & & 24,6 & & 13,6 (Ind), 54,5 (Other) \\
Glina & $\mathbf{6 7 , 8}$ & & & 29,7 (HDZ) \\
Gračac & 37,4 & 27,9 & & 26,7 (Ind) \\
Knin & & 69,8 & 20,9 & $\mathbf{7 , 2}$ (HDZ) \\
Kostajnica & & & 62,1 & 20,6 (Ind) \\
Obrovac & 42,9 & & & 34,2 (HDZ), 21,0 (Ind) \\
\hline Petrinja & 58,3 & & & 24,9 (KNS) \\
Slunj & 44,4 & & & $\mathbf{5 3 , 6}$ (HDZ) \\
\hline T. Korenica & $\mathbf{8 0 , 3}$ & & & 48,9 (JS-DS) \\
Vojnić & 49,1 & & & 18,6 (Ind) \\
\hline Vrginmost & $\mathbf{6 8 , 0}$ & & & \\
\hline
\end{tabular}

" "Other" is not specified in the source.

* Although in the table the first round result for Vojnić was undecided, my source gives no result for a second round.

${ }^{38}$ I have not considered the later elections of 1992, for three principal reasons. War had already begun then, and electoral behaviour could be construed as a reflection of that fact, rather than as an indication of antecedent political culture. The Serbian Democratic Party in Croatia had split by then, with the more accommodationist Serbian National Party (under Milan Djukić) co-operating with the electoral system. The electoral law was also changed in the interval, and by this time the Serb political vote was largely reflected in national "lists" rather than in votes for territorial constituencies. 
Chamber of Municipalities - $2^{\text {nd }}$ Round (May 6, 1990)

(Other constituencies decided in $1^{\text {st }}$. round)

\begin{tabular}{|c|c|c|c|c|}
\hline Commune & SDP & SDS & SS-SSH & Other \\
\hline Benkovac & 7,0 & & 53,1 & 37,6 (HNS) \\
\hline Donji Lapac & & 54,1 & & 43,5 (Other) \\
\hline Dvor & & 21,3 & & $\mathbf{5 5 , 4}$ (Other), 8,5 (Ind) \\
\hline Gračac & 25,6 & 55,5 & & 14,2 (Ind) \\
\hline Kostajnica & 72,5 & & & 24,3 (Ind) \\
\hline Obrovac & 49,3 & & & 35,0 (HDZ), 14,7 (Ind) \\
\hline
\end{tabular}

Source : Ivan Grdešić, Mirjana Kasparović, Ivan Šiber and Nenad Zakošek, Hrvatska u izborima '9o. Zagreb : Naprijed, 1991, pp. 208-210 and 214-216.

$\begin{array}{ll}\text { HDZ } & \text { Hrvatska Demokratska Zejednica } \\ \text { Ind } & \text { Independent } \\ \text { JS-DS } & \text { Jugoslavenska Stranka-Demokratska Stranka } \\ \text { KNS } & \text { Koalicija Nacionalne Solidarnost } \\ \text { SDS } & \text { Srpska Demokratska Stranka } \\ \text { SKH-SDP } & \text { Savez Komunista Hrvatske-Socijaldemokratska Stranka Hrvatske } \\ \text { SS-SSH } & \text { Socijalistički Savez-Stranka Socijalista Hrvatske }\end{array}$

The overall tendency of Serbs to vote for the League of Communists (LC) and its successors (with the aim of preserving an integral Yugoslavia) is marked. Expressly socialist parties created by the LC and the Socialist Alliance captured the seats in the Chamber of Municipalities in Glina, Titova Korenica and Vrginmost, in the first round (22 April), and in Benkovac, Kostajnica and Obrovac in the second round (6 May). Rašković's Serbian Democratic Party (SDS) took seats in Knin ( $1^{\text {st }}$ round) and Donji Lapac and Gračac ( $2^{\text {nd }}$ round). The SDS also polled strongly in Dvor. It did not field candidates elsewhere-even in those parts of central Slavonia (Daruvar, Pakrac and Podravska Slatina) in which there were large Serb populations 39 . Here the ethnic diversity of the population gave a distinct advantage to left parties which did not adopt a specifically ethnic identity, but which took a broadly pro-Yugoslav stance. Neither did it hold out any appeal to the Serb minority in Zagreb, where no SDS candidates were fielded. (In fact, Šibenik was the only constituency outside the krajina in which the SDS was able to put up a candidate, and here it performed poorly in comparison with non-ethnic parties, in opposition to Tudjman's

39 I have excluded these three communes from consideration for several reasons, although an attempt was made to incorporate them into the krajina. They were only partially integrated, spatially, into the secessionist Serb project, partly because of their ethnic diversity. Daruvar (32,2\% Serb in 1991) had large Czech, Magyar and other minorities ; Pakrac (46,4\% Serb) had large minorities of Czechs, Italians and "Yugoslavs") ; Podravska Slatina (35,8 \% Serb) was also diverse, with a large "Yugoslav" component. They all contained quite substantial towns (27000-31000), and were mid-ranking in terms of their economic development. 
Croatian Democratic Union-HDZ). Independent and fringe party candidates also performed well among the Serbs of the krajina, and these invariably took strongly nationalist and localist positions. This point has been made in relation to Bosnia by Xavier Bougarel.

Study of the results of the elections reveals a particularly homogeneous vote in favour of the nationalist parties in those regions which were economically under-developed and ethnically homogeneous, among the rural or semiurban population and among the lower and less-educated socio-professional groups. $4^{\circ}$

It seems that the areas which attempted to secede from Croatia as the Serbian krajina possessed a distinctive political culture which owed its character in part to the isolation and economic backwardness of predominantly rural settlements.

The failure to perceive the significance of these differences, it can be argued, was fatal for the development of Croatian politics. The insensitivity with respect to Serbs which has been laid at the door of Franjo Tudjman and the $\mathrm{HDZ}$ may well be attributable in large measure to two factors.

In spite of the formal assurances given to Serbs by the Sabor, that their position as Croatian citizens was not in question, $\mathrm{HDZ}$ political campaigning persistently worked on the association between "Serb" and "Communist" 41 . This is certainly suggested by the character of early HDZ propaganda, which also tended to extract political advantage from contrasting the Catholicism of true Croats with the secularism or atheism of Serb / Communists. Although there was a tendency to demonise Serbs as an alien and hostile force in the country, perceptions of their political effectiveness as opposition to the HDZ was minimised by blindness to the distinctiveness of political culture in the krajina, and a tendency to believe that the more accommodationist Serbs who were prominent in Zagreb politics, such as Milan Djukić, could be taken as representing "Serb" opinion. This picture of Serb culture spectacularly missed the point in relation to the rural heartland of Croatian Serbdom, and probably contributed directly to the failure of the Croatian government to engage seriously with the constitutional and more broadly political problems raised by the republic's Serb minority.

$4^{\circ}$ Bougarel (Xavier), op.cit, p. 46.

$4^{1}$ In particular, the claim was made much of by Franjo Tudjman. (In Tudjman (Franjo), Nationalism in Contemporary Europe, New York : East European Monographs, 1981, esp. pp. 145 ff.) that minority groups in Croatia had successfully used the apparatus of the LC as a means of social mobility. This material is treated more fully and in a more balanced fashion in Cohen (Lenard), The Socialist Pyramid, London : Triservices Press, 1989. 


\section{CASE STUDIES : [II] « HERCEG-BOSNA 》}

Some related, general points could be made in relation to the social character of the Croat municipalities which formed the core of "Herceg-Bosna"the secessionist ethnic Croat enclave centred upon western Herzegovina, within the Republic of Bosnia and Herzegovina.

The settlement of ethnic Croats in Bosnia-Herzegovina was, on the whole, highly dispersed. There were three principal areas, however, in which they made up a significant proportion of the population : the industrial region of central Bosnia, western Herzegovina, and the Posavina (see Table 4). The republican capital, Sarajevo, might be considered a distant fourth, and here the numerical concentration of Croats was masked by their tendency to absorption in a large, multi-ethnic city. (Together these four areas accounted, in 1991, for two thirds of the Croat population of the republic.) The second of these regions was highly distinctive, in that only in this group of communes did ethnic Croats make up more than $75 \%$ of the population; and only here did the preponderant majority of the population reside in rural or near-rural settlements. As a consequence, Croatian culture in BosniaHerzegovina is historically very diverse. Our attention centres upon western Herzegovina.

\section{Table 4 : Concentrations of the Ethnic Croat Population of Bosnia and Herzegovina [Census of 1991]}

\begin{tabular}{|l|c|c|}
\hline & $\begin{array}{c}\text { Ethnic Croats: } \\
\text { N }\end{array}$ & $\begin{array}{c}\text { Percentage of ethnic } \\
\text { Croats in the Republic }\end{array}$ \\
\hline Bosnia and Herzegovina & 755895 & 100,00 \\
\hline Greater Sarajevo & 34867 & 4,61 \\
\hline Western Herzegovina & 183253 & 24,20 \\
\hline Central Bosnia & 150605 & 19,90 \\
\hline The Posavina & 128741 & 17,01 \\
\hline
\end{tabular}

Source : Concise Atlas.

The western Herzegovinian communes of Čapljina, Čitluk, Grude, Široki Brijeg (Lištica), Livno, Ljubuški, Neum, Posušje, Prozor and Tomislavgrad (Duvno) each reported fewer than 30 ooo inhabitants at the 1991 census. Of these, only Livno contained an urban settlement with a population greater than 10 ooo. Only Prozor (62,3\%) and Čapljina (53,9 \%) had ethnic Croat ma- 
jorities smaller than $80 \%$. Together they contained around a quarter of the ethnic Croat population of Bosnia and Herzegovina $4^{2}$.

As with the Serb krajina within Croatia, this area had experienced a steady demographic decline. These municipalities had experienced, since the 1970 , some of the highest rates of external migration not only in the republic but in the entire Yugoslav federation 43 . (The seriousness of this situation is masked in Table 1 by their rates of natural increase.) Between 1971 and 1991 the percentage of the population of the republic reported as on temporary work abroad rose from 3,67 to 5,10. In only one of the ten municipalities considered here (Čapljina) was the rate of increase below the average for the republic, and the average rate for the group in 1991 was $14 \%$. In the census of 1991 Tomislavgrad reported $27 \%$ of its total population as workers abroad or their dependants.

Not only were these communities mainly small, rural and solidly Croat, therefore, they were also for the most part in dire economic straits. In these ten municipalities, which provided the initial core of "Herceg-Bosna", average wages were a fifth lower than for the republic as a whole : GNP per capita was approximately $45 \%$ of the levels found in the larger cities of the Republic. In fact, with the localised exceptions of Čapljina (containing the pilgrimage centre of Medjugorje, and standing astride the important communications corridor of the Neretva valley), Široki Brijeg and Livno (the only significant industrial locale) all of this group falls into the lowest quartile of communes in the republic, in relation to levels of nett income per capita in social sector employment (Table 2) 44 .

Levels of economic backwardness in fact rivalled those of Kosovo : and this level of poverty is the more remarkable in that the region did not have to contend with the burden of the exceptionally high birth-rates which characterised the latter. The "Herceg-Bosna" project has often been the butt of the gibe that western Herzegovina contains " only rocks, snakes and ustaša ". Whereas it is undoubtedly the case that this is an exaggeration on all three counts, the link which it makes between economic depression and political extremism is undoubtedly soundly based.

\footnotetext{
$4^{2}$ Note that Mostar is excluded from consideration here, despite vigorous attempts by the Croats to incorporate it into Herceg-Bosna. The situation of Mostar is quite different from that of the area considered here. See below, note 49.
}

43 Statistički Godišnjak Republike Bosne i Hercegovine : 1992, Sarajevo : Državni Zavod za Statistiku, 1994, Table I-5, pp. 308-310. Figures for 1971 from Baučić (Ivo), ed., Radnici u inozemstvu prema popisu stanovništva Jugoslavije 1971, Zagreb : Institut za Geografije Sveučilišta u Zagrebu, 1973, pp. 153-155.

44 I am still somewhat puzzled by the uncharacteristic position of Široki Brijeg in this comparison. Bill Tomljanović has pointed out that " Široki Brijeg is the center of what they sometimes euphemistically call "import-export". In America we call it "the family". In other words, Široki Brijeg is the Croatian Palermo n. (Personal communication.) This is an interesting and suggestive idea, but I wonder whether it did not acquire this status most significantly after the events in question. I await elucidation! 
The diversity of Croatian culture in Bosnia-Herzegovina appears at a number of levels, including the divisions within the Roman Catholic Churchmarked by, for example, the close association between the population of western Herzegovina and the Franciscan order, in the conflict of interpretations which arose over the events in Medjugorje. (The local friars supported the visionaries against the scepticism not only of the secular authorities but also the hierarchy in Sarajevo45).

This diversity is manifested also at the level of political culture $4^{6}$. Croatian political opinion in Bosnia and Herzegovina, around the time of the break-up of the former Communist hegemony, did not have the diversity of organisational expression seen among the Serbs of Croatia. The general discredit of the IC in the republic in the 1980 s meant that there was no strong, reformed socialist voice in the republic. Ante Marković's attempt to create a multi-ethnic, modernising force in his Alliance of Reform Forces came too late to have much of an impact on the pattern of party formation and voting behaviour in the first multi-party elections. Consequently, the Croatian Democratic Union in Bosnia and Herzegovina (HDZ BH) was founded as an offshoot of the parent body in Zagreb, and in the first multi-party elections emerged as the unchallenged voice of ethnic Croats throughout the republic. In its early days it was dominated by a group of educated urbanites based in Sarajevo, of which Stjepan Kljujić can be seen as representative. Despite powerful groups within the HDZ BH who throughout retained doubts about the possibility or desirability of supporting the continuing integrity of a united republic of Bosnia and Herzegovina, the party participated in the coalition government formed after the first multi-party elections of November 1990.

Slovenia and Croatia declared their independence from the federation in June 1991, following which, in October, a proposal to consider independence was laid before the Assembly in Sarajevo. Serb representatives promptly withdrew from the Assembly, set up their own parliament in Pale, and organised a referendum on independence on November 9-10.

\footnotetext{
45 See, for example, Markle (Gerald E.), McRea (Frances B.), "Medjugorje and the crisis in Yugoslavia ", in Swatos (William H.), ed., Politics and Religion in Central and Eastern Europe : traditions and transitions, Westport / London : Praeger, 1994 .

${ }^{6} 6$ It is striking that this distinctiveness can be traced back into the "First Yugoslavia". Ivo Banac shows very clearly that the Radic brothers' Croatian Peasant Party had no support among Croats of Bosnia and Herzegovina. Instead, the vote of western Hercegovina went to the Hrvatska Pučka Stranka (Croatian People's Party) and the Narodni Klub (National Club). The first of these was strongly Catholic in orientation : the second a coalition of extreme nationalist fragments, which included at that time Ante Pavelic. See, Banac (Ivo), op.cit., esp. maps on pp. 228, 350 and 355.
} 
The leadership of Bosnia's Croats immediately became concerned about the possibility that they might be compelled by the Serbs to remain as an increasingly subordinated minority within a Yugoslavia totally dominated by Serbs. Alternatively, given the possible secession of majority-Serb areas, and distrusting the good-will of the (Muslim) Party of Democratic Action, they feared that they could become reduced to the status of a minority within a predominantly Muslim state. On 18 November 1991, therefore, the "Croatian Community of Herceg-Bosna" was founded. At first this was expressly intended as an organisation to defend the interests of Bosnian Croats throughout the republic, rather than as the government of a secessionist state. Its articles of association declared that : "The Community will respect the democratically elected government of Bosnia and Herzegovina while it upholds the independence of the state of Bosnia and Herzegovina in relation to the former or any future Yugoslavia "47. Nevertheless, over the winter of 19911992 a struggle took place within the leadership of the HDZ BH which resulted, by February 1992, in the resignation of Kljujic and the installation of a new, radically nationalist leadership. The earlier leadership including Franjo Boras, Ivan Markezić, Marofil Ljubić and Jure Pelivan was replaced by a group led by Mate Boban, and including Ignac Kostroman, Dario Kordić and Anto Valenta. The former conciliatory stance of the party towards maintaining a unified state and a multi-ethnic republic was abandoned, to be replaced by the vision of "Herceg-Bosna" as an openly secessionist, expressly Croat, state ${ }^{8}$. This centred upon the solidly Croat areas of western Herzegovina, which have been the subject of the foregoing discussion, with its "capital" in Grude.

At one level western Herzegovina might be regarded as almost worthless as a prize, containing as it did few inhabitants, insignificant economic resources, and being of little importance from the point of view of communication. Throughout the war the principal efforts of the Bosnian Croat leadership, at both the military and political levels, were directed towards securing command of a "triangle of control" in central Bosnia (defined by Jajce, Jablanica

47 Narodni List HZ HB, rujan 1992, br.1.

${ }^{48}$ In preparing this paper I have become acutely aware of the historical controversies which remain to be clarified in this area. These particularly concern the timing of key events, and the relative causal importance of events within Bosnia-Hercegovina or in its wider context-both internationally and in relation to the Croatian leadership. This is not the occasion on which to attempt to resolve these issues. 
and Sarajevo) and the Neretva Valley ${ }^{49}$. Nevertheless, the fact that the loyalty of the population of this core area, to the project of the secession of a homogeneous Croat state, could be absolutely relied upon, made it ideal as a base from which expansion northwards and eastwards could be pursued.

\section{CONCLUSION}

At the most general level, the claim that " no explanation [for the breakup of Yugoslavia] which does not place at its heart economic factors deserves to be taken seriously " under-girds the argument of this paper ${ }^{\circ}$. Bearing in mind that wider explanatory context, however, it is certainly not my contention that the disintegration of the Yugoslav federation can be explained solely and simply by reference to a succession of conflicts between the cities and backward rural areas. Above all, I have a lively awareness of the need to avoid the perception warned against by Bojan Baskar ${ }^{51}$. I have no wish to associate myself with the common practice of blaming the victim !

It is my belief, nevertheless, that no attempt to understand the genesis and evolution of the crisis which led to the disintegration of Yugoslavia, which neglects the dimension of rural-urban conflict, can pretend to anything approaching adequacy.

I suggest that the ressentiment of backward rural areas towards the metropolis could be one among the array of explanatory factors which need to be addressed. In looking for explanations for the phenomenon of secessionism, I hypothesise that we need to take into consideration the profound state of eco-

49 See Allcock (John B.), Aspects of Ethnicity, Nationality and Nationalism in the former Yugoslavia, op.cit., Part 1-G and Maps 7 and 8. Two areas within the republic of Bosnia and Herzegovina have been of particular strategic importance. Western Herzegovina, and especially the lower Neretva valley, which includes the town of Mostar, has been of exceptional significance, in that control of this area potentially permits Croatia to control a very high proportion of the trade of Bosnia, as well as secure surface access to the tourist potential of Medjugorje. The Neretva estuary is also a very productive area of agricultural land. Although lying outside of the region of almost homogeneous ethnic Croat settlement which provided the core of "Herceg-Bosna", a triangle of 17 municipalities extending between Jajce, Sarajevo and Jablanica (excluding those which form part of "Greater Sarajevo") constituted one of the primary objectives of the HVO during the war. Only three of these municipalities (Kiseljak, Kreševo and Prozor) had ethnic Croat majorities, and there were absolute Muslim majorities in 7 of them. The prize for control of this area, however, was plainly its economic significance rather than the desire to secure the cultural autonomy of its Croat population. It commands the main rail links Sarajevo-Metković and Sarajevo-Zenica (in effect regulating the entire rail network of Bosnia and Herzegovina). It encompasses a very high proportion of the power generation capacity of the republic, especially the hydro-electric facilities in the vicinity of Jablanica, along the Vrbas and the Rama, the coal and iron ore resources in the vicinity of Zenica, and useful manufacturing (especially engineering) capacity associated with these.

50 The quotation is from Allcock (John B.), Explaining Yugoslavia, op.cit., p. 89.

${ }^{51}$ See above, note 11. 
nomic depression into which these areas had fallen, even where (in the case of the Serb krajina in Croatia) they were located in one of Yugoslavia's more prosperous republics. The two illustrations explored in a rudimentary manner here are intended to provide a stimulus to the wider investigation of these issues. From studies such as this it will be possible to piece together a more complete picture of the diversity of local responses to the Yugoslav economic and political crisis, and to provide a more complete understanding of the ways in which local, state-wide and international factors interacted in the causation of Yugoslavia's collapse into war. 